\title{
Feeding Programs for Broiler Breeders in the Start Phase
}

qAuthor(s)

Tremarin J'

Sakamoto MI

Universidade Camilo Castelo Branco - UNICASTELO; Departamento de Produção Animal. Av. Hilário da Silva Passos, 950 - CEP 13690-900 - Descalvado, SP - Brasil; Email: jandreipt@hotmail.com; mizumiss@yahoo. com.br

\section{ABSTRACT}

The fast-growing Brazilian aviculture requires studies to improve zootechnical performance indexes for broiler breeders. The purpose of this study was to assess different feeding programs for broiler breeders on performance and development of digestive organs. A total of 48,000, $1 \mathrm{~d}$-old, Cobb 500 broiler breeders were divided into two sheds with 24,000 birds each. The experiment was randomized in block design, considering each shed a block, with 4 treatments and 6 replications per treatment with 2,000 birds in each. Treatments consisted of: Shed 1) T1 $=$ starter feed; $\mathrm{T} 2=\mathrm{T} 1+$ probiotics; Shed 2$) \mathrm{T} 3=$ pre-starter feed; $\mathrm{T} 4=\mathrm{T} 3$ + probiotics. The productive performance characteristics (bird weight, weight gain, feed intake and feed conversion), the development of digestive organs (gizzard, proventriculus, spleen, bursa of Fabricius and small bowel) as well as the small bowel length were assessed weekly for all experimental groups, in samples of 10 birds per treatment. The best feed conversion and weight gain were observed with pre-starter feed in the first 7 days of age, with or without probiotic. Small bowel, gizzard and proventriculus development at 28 days was better for birds on prestarter feed compared to those on starter feed alone. It is possible to conclude that broiler breeders on pre-starter feed during the first 7 days of age are likely to show better physical and productive performances in the adult phase.

\section{INTRODUCTION}

The broiler breeder segment has been going through oscillations due to the combination of a reduction in supply (as a result of problems in parent and grandparent broiler houses, or sanitation issues) and an increase in demand (due to high beef prices, for example). In these cases, eggs or chicks that were likely to be excluded in a more detailed selection $_{\iota}$ are maintained for growing and finishing. Eggs from new breeders will provide one-day chicks with more substantial weight variation, which might compromise the performance of the flock (Burnham et al., 2001).

The bird's size and weight, 1-d-old are considered key factors for flock uniformity; broiler breeders between 30-55 weeks of life produce chicks of $40-45 \mathrm{~g}$ of live weight, considered ideal for development (Cobb 500). Thus, the post-hatch feeding of birds is very important for this purpose.

Due to limitations in the digestion and absorption of nutrients, several factors influence growth rates in the first week - percentage of yolk, feed and water intake, nutritional value, amount of feed and microbiota colonization (Dibner et al., 2008).

High quality feed in the first days of age may contribute to maximum genetic performance. Different feeding programs have been assessed 
considering the nutritional requirements at each stage of life, so that birds reach maximum zootechnical indexes while reducing costs and improving growth (Godoy, 1994).

The feed is the main cost in aviculture, reaching up to $70 \%$ of costs, therefore, several companies are focusing on specific feeds for each stage of life, meeting nutritional requirements and improving bird uniformity and performance. However, several factors affect nutrient utilization, such as the age of the birds, digestibility of feed ingredients and management practices (Lilburn, 1998).

Brake (1999), demonstrated the importance of the relationship between the cumulative nutrition during the period of breeding and rearing and future reproductive performance of females. This period ranges from accommodation to photostimulation.

The aim of this study was to assess different feeding programs for broiler breeders in the starter phase (1 to 28 day old), considering performance and digestive organs development.

\section{MATERIAL AND METHODS}

The experiment was performed in the Agua Vermelha Poultry House, partner of Globoaves, located near the city of Sao Carlos - SP (Brazil), from August to September 2013. The study was approved by the Ethics Committee in Animal Use from UNICASTELO, under protocol number 0001/2014.

The fowl run has negative pressure, with black curtains, $18.8 \mathrm{~m}$ in length and $16.5 \mathrm{~m}$ in width and a commuting water cooler.

The total of forty-eight thousand female, 1 day old, Cobb broiler breeders were divided into two sheds, with twenty-four birds each. The experiment was randomized in block design, considering each shed a block, with four treatments and six replications per treatment with 2,000 birds each (eight birds $/ \mathrm{m}^{2}$ of creating density). The treatments consisted of: Shed 1) $\mathrm{T} 1$ = starter feed (1-7 days); $\mathrm{T} 2=\mathrm{T} 1+$ probiotic (in continuous water on day 1); Shed 2) T3 = pre-starter feed (1-7 days); $\mathrm{T} 4=\mathrm{T} 3$ + probiotic (in continuous water on day 1). After 7 days, all birds were fed the same control diet (T1) without probiotic. Experimental diets were corn and soymeal-based, meeting the nutritional requirements of each feeding stage (Manual COBB500) - Table 1.

Floramax (live lactobacillus) was the probiotics of choice. It includes Lactobacillus Bulgaricus, Lactobacillus Casei, Lactobacillus Cellobiosus, Lactobacillus
Table 1 - Centesimal and calculated composition of experimental feeds for broiler breeders in starter phase.

\begin{tabular}{lll}
\hline Ingredients & Pre-starter & Starter \\
\hline Corn, ground & 51.405 & 60.865 \\
\hline Wheat bran & 0.000 & 4.000 \\
\hline Soy bran - 45\% & 40.550 & 29.800 \\
\hline Soy oil & 3.650 & 0.250 \\
\hline Calcitic limestone - 38\% & 1.475 & 1.525 \\
\hline Monodicalcium phosphate - 20\% & 1.250 & 1.025 \\
\hline Salt & 0.295 & 0.305 \\
\hline Sodium bicarbonate & 0.310 & 0.140 \\
\hline Methionine1 - 88\% & 0.320 & 0.285 \\
\hline Lysine ${ }^{2}$ - 54,6\% & 0.100 & 0.190 \\
\hline L-threonine ${ }^{3}$ - 98\% & 0.045 & 0.015 \\
\hline Vitamin-mineral premix ${ }^{4}$ & 0.400 & 0.400 \\
\hline Kaolin & 0.000 & 1.000 \\
\hline Antifungals ${ }^{5}$ & 0.200 & 0.200 \\
\hline Total & 100.00 & 100.00 \\
\hline Calculated composition & & \\
\hline Metabolizable Energy (kcal/kg) & 2.999 & 2.850 \\
\hline Crude Protein (\%) & 23.00 & 19.49 \\
\hline Crude Fiber (\%) & 3.10 & 3.13 \\
\hline Calcium (\%) & 1.05 & 1.00 \\
\hline Total phosphorus (\%) & 0.61 & 0.56 \\
\hline Digestible lysine (\%) & 1.18 & 1.00 \\
\hline Digestible methionine (\%) & 0.54 & 0.47 \\
\hline Digestible tryptophan (\%) & 0.25 & 0.21 \\
\hline Digestible treonine (\%) & 0.81 & 0.65 \\
\hline Digestible methionine+cysteine (\%) & 0.85 & 0.75 \\
\hline Sodium (\%) & 0.23 & 0.19 \\
\hline Chlorine (\%) & 0.24 & 0.25 \\
\hline Potassium (\%) & 0.95 & 0.80 \\
\hline DEB (mEq/kg) & 277 & 195 \\
\hline DL--men & \\
\hline
\end{tabular}

${ }^{1}$ DL-methionine (Ajinomoto Int. $®$ ). ${ }^{2}$ Biolys (Evonik Degussa $\left.®\right) ;{ }^{3}$ L-Threonine (Ajinomoto Int. $($ )

${ }^{4}$ Vitamin-mineral premix composition (per $\mathrm{kg}$ ) - Pre-starter/starter: vitamin A $11250000 \mathrm{Ul} / \mathrm{kg}$, Vitamin D3 $3750000 \mathrm{Ul} / \mathrm{kg}$, Vitamin E $37500 \mathrm{mg} / \mathrm{kg}$, Vitamin K3 $3125 \mathrm{mg} / \mathrm{kg}$, Vitamin B1 3125 mg/kg, Vitamin B2 10000 mg/kg, Vitamin B6 5000 mg/ kg, Vitamin B12 25000 mcg/kg, Niacin 50000 mg/kg, Pantothenic Acid 18750 mg/ kg, Folic Acid $2000 \mathrm{mg} / \mathrm{kg}$, Biotin $150 \mathrm{mg} / \mathrm{kg}$, Colin chloride $60 \% 1250 \mathrm{~g} / \mathrm{kg}$, Copper $10000 \mathrm{mg} / \mathrm{kg}$, Iron $50000 \mathrm{mg} / \mathrm{kg}$, Manganese $120000 \mathrm{mg} / \mathrm{kg}$, Zinc $100000 \mathrm{mg} / \mathrm{kg}$, lodine $2000 \mathrm{mg} / \mathrm{kg}$, Selenium $300 \mathrm{mg} / \mathrm{kg} ;{ }^{5}$ EBD $100 \mathrm{mg} / \mathrm{kg} 125 \mathrm{mg} / \mathrm{kg} ;{ }^{6}$ Electrolyte Balance of Diet, according to Mogin (1981).

Fermentum, Lactobacillus Helveticus and inulin (Vetan$\left.\mathrm{CO}^{\circledR}\right)$, one sachet of $50 \mathrm{ml}$ to 10.000 birds.

The lighting program was defined as 24 hours of light on the first day of lodging, with 2 hours/day reductions until 10 hours/day of light was reached. Maximum and minimum temperatures were recorded daily with a mercury thermometer, with averages of $32^{\circ} \mathrm{C}$ and $20^{\circ} \mathrm{C}$, respectively.

On day 3 , beaks were trimmed and the birds were vaccinated via eye drop against infectious bronchitis, Newcastle, Gumboro, and coccidiosis; at 21 days the birds were given a Gumboro boster via drinking water. 
Zootechnical performance indexes (body weight, feed consumption, feed conversion and flock viability) were assessed weekly throughout the experimental period. The feed was offered ad libitum in the first week. From the second week onwards, the feed was controlled when each bird received the required amount according to lineage and age. The amounts were adjusted weekly according to the Lineage Manual.

At 7, 14, 21 and 28 days, 10 birds per treatment were euthanized and necropsied, and the following variables were assessed: bird weight, weight of proventriculus, gizzard, cloacal bursa, small bowel and gut length. The organ's weights were given relative to the bird's weight.

Data were submitted to variance analysis in a randomized block design, and means were compared by $t$ test at $5 \%$ probability level, with SAS statistical package (2002).

\section{RESULTS AND DISCUSSION}

The results of performance characteristics of breeders in starter phase are shown in Table 2. Higher body weight was observed $(p<0.05)$ at 7,14 and 21 days for birds fed with pre-starter feed in the first 7 days of age, regardless of probiotics use. Feed conversion was also better for these groups at 14 and 21 days, even though feed was controlled after 7 days of age.
For broiler breeders, controlled feed is crucial for flock uniformity, the modern strains of high performance have large capacity on muscle growth, and even when mature birds can still convert the excess of amino acids and proteins in muscles, impairing egg production (Jensen, 1986).

In the whole assessment period (1-28 days, Table $3)$, higher daily weight gain can be observed for birds on pre-starter feed when compared to those receiving starter feed alone, with direct influence on feed conversion.

Table 4 shows the relative weights of the digestive tract organs at 1, 7, 14, 21 and 28 days for the different treatments. The difference was significant $(p \leq 0.05)$ for all variables, except relative liver weight. In agreement with the studies of Penz et al. (1998) and Stringhini et al. (2003), higher development of small bowel can be observed in the fisrt week for all birds, regardless of treatment, highlighting the importance of specific diets which meet the nutritional requirements of posthatch birds. However, gut relative weight was higher $(p \leq 0.05)$ at 28 days for the birds which received pre-starter feed with or without probiotics, when compared to birds fed only with starter feed, regardless of probiotics.

The small bowel was longer at 28 days for birds on pre-starter feed without probiotics when compared to birds fed with starter feed with or without probiotic.

Table 2 - Average scores ${ }^{1}$ for weekly performance of broiler breeders in grower phase on different feeding programs.

\begin{tabular}{|c|c|c|c|c|c|c|c|c|c|c|c|c|}
\hline \multirow[t]{2}{*}{ Characteristics } & \multicolumn{3}{|c|}{ Starter } & \multicolumn{3}{|c|}{ Starter+probiotics } & \multicolumn{3}{|c|}{ Pre-starter } & \multicolumn{3}{|c|}{ Pre-starter + probiotics } \\
\hline & \multicolumn{9}{|c|}{ Between days 1-7 } & & & \\
\hline BW - day 1 (g) & 37.92 & \pm & 1.24 & 37.92 & \pm & 1.24 & 36.96 & \pm & 1.00 & 36.96 & \pm & 1.00 \\
\hline BW - day 7 (g) & 125.00 & \pm & $10.23 \mathrm{~b}$ & 125.00 & \pm & $10.23 b$ & 133.00 & \pm & $10.65 a$ & 133.00 & \pm & $10.65 a$ \\
\hline DWG (g) & 12.44 & \pm & 1.04 & 12.44 & \pm & 1.04 & 13.72 & \pm & 1.87 & 13.72 & \pm & 1.87 \\
\hline DFI (g/bird/day) & 22.00 & \pm & 0.00 & 22.00 & \pm & 0.00 & 22.00 & \pm & 0.00 & 22.00 & \pm & 0.00 \\
\hline $\mathrm{FCR}(\mathrm{g} / \mathrm{g})$ & 1.768 & \pm & 0.65 & 1.768 & \pm & 0.65 & 1.603 & \pm & 0.40 & 1.603 & \pm & 0.40 \\
\hline \multirow[t]{2}{*}{ Liveability (\%) } & 99.58 & \pm & 0.45 & 99.67 & \pm & 0.32 & 99.20 & \pm & 0.50 & 99.11 & \pm & 0.80 \\
\hline & \multicolumn{9}{|c|}{ Between days 8-14 } & & & \\
\hline BW - day 7 (g) & 125.00 & \pm & $10.23 \mathrm{~b}$ & 125.00 & \pm & $10.23 \mathrm{~b}$ & 133.00 & \pm & $10.65 \mathrm{a}$ & 133.00 & \pm & $10.65 \mathrm{a}$ \\
\hline BW - day 14 (g) & 220.00 & \pm & $18.5 b$ & 220.00 & \pm & $18.5 b$ & 273.00 & \pm & $17.8 \mathrm{a}$ & 273.00 & \pm & $17.8 \mathrm{a}$ \\
\hline DWG (g) & 13.57 & \pm & $1.9 \mathrm{~b}$ & 13.57 & \pm & $1.9 \mathrm{~b}$ & 20.00 & \pm & $2.1 \mathrm{a}$ & 20.00 & \pm & $2.1 \mathrm{a}$ \\
\hline DFI (g/bird) & 34.00 & \pm & 0.00 & 34.00 & \pm & 0.00 & 34.00 & \pm & 0.00 & 34.00 & \pm & 0.00 \\
\hline $\mathrm{FCR}(\mathrm{g} / \mathrm{g})$ & 2.505 & \pm & $0.78 \mathrm{a}$ & 2.505 & \pm & $0.78 \mathrm{a}$ & 1.700 & \pm & $0.62 b$ & 1.700 & \pm & $0.62 b$ \\
\hline \multirow[t]{2}{*}{ Liveability (\%) } & 99.54 & \pm & 0.40 & 99.79 & \pm & 0.25 & 99.64 & \pm & 0.32 & 99.65 & \pm & 0.45 \\
\hline & \multicolumn{9}{|c|}{ Between days $15-21$} & & & \\
\hline BW - day 14 (g) & 220.00 & \pm & $18.5 \mathrm{~b}$ & 220.00 & \pm & $18.5 b$ & 273.00 & \pm & $17.8 \mathrm{a}$ & 273.00 & \pm & $17.8 \mathrm{a}$ \\
\hline BW - day 21 (g) & 330.00 & \pm & $20.3 b$ & 330.00 & \pm & $20.3 b$ & 400.00 & \pm & $23.5 \mathrm{a}$ & 400.00 & \pm & $23.5 \mathrm{a}$ \\
\hline DWG $(g)$ & 15.71 & \pm & $1.36 b$ & 15.71 & \pm & $1.36 b$ & 18.14 & \pm & $1.8 \mathrm{a}$ & 18.14 & \pm & $1.8 \mathrm{a}$ \\
\hline DFI (g/bird) & 42.00 & \pm & 0.00 & 42.00 & \pm & 0.00 & 42.00 & \pm & 0.00 & 42.00 & \pm & 0.00 \\
\hline $\mathrm{FCR}(\mathrm{g} / \mathrm{g})$ & 2.673 & \pm & $0.56 \mathrm{a}$ & 2.673 & \pm & $0.56 \mathrm{a}$ & 2.315 & \pm & $0.42 b$ & 2.315 & \pm & $0.42 b$ \\
\hline Liveability (\%) & 99.91 & \pm & 0.15 & 99.92 & \pm & 0.10 & 99.73 & \pm & 0.26 & 99.77 & \pm & 0.15 \\
\hline
\end{tabular}

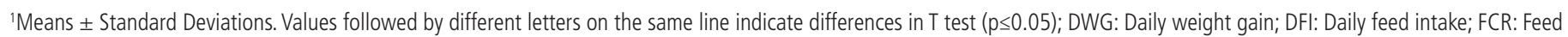
conversion ration; BW: Body weight. 
Table 3 - Mean values ${ }^{1}$ of performance characteristics of broiler breeders throughout grower phase (days 1-28) receiving different feeding programs.

\begin{tabular}{lccccccccccccc}
\hline Characteristics & \multicolumn{3}{c}{ Starter } & \multicolumn{3}{c}{ Starter+probiotics } & \multicolumn{3}{c}{ Pre-starter } & \multicolumn{3}{c}{ Pre-starter + probiotics } \\
\hline BW - day 1 (g) & 37.92 & \pm & 1.24 & 37.92 & \pm & 1.24 & 36.96 & \pm & 1.00 & 36.96 & \pm \\
BW - day 28 (g) & 491.00 & \pm & $23.5 \mathrm{~b}$ & 491.00 & \pm & $23.5 \mathrm{~b}$ & 543.00 & \pm & $20.3 \mathrm{a}$ & 543.00 & \pm & $20.3 \mathrm{a}$ \\
DWG (g) & 16.18 & \pm & $1.23 \mathrm{~b}$ & 16.18 & \pm & $1.23 \mathrm{~b}$ & 18.07 & \pm & $1.48 \mathrm{a}$ & 18.07 & \pm & $1.48 \mathrm{a}$ \\
DFI (g/bird) & 36.00 & \pm & 0.00 & 36.00 & \pm & 0.00 & 36.00 & \pm & 0.00 & 36.00 & \pm & 0.00 \\
FCR (g/g) & 2.225 & \pm & $0.38 \mathrm{a}$ & 2.225 & \pm & $0.38 \mathrm{a}$ & 1.992 & \pm & $0.32 \mathrm{~b}$ & 1.992 & \pm & $0.32 \mathrm{~b}$ \\
Liveability (\%) & 98.96 & \pm & 0.56 & 99.32 & \pm & 0.20 & 98.40 & \pm & 0.65 & 98.40 & \pm & 0.75 \\
\hline
\end{tabular}

${ }^{1}$ Means \pm Standard Deviations. Values followed by different letters on the same line indicate differences in T test ( $\left.p \leq 0.05\right)$; DWG: Daily weight gain; DFI: Daily feed intake; FCR: Feed conversion ration; BW: Body weight.

According to Windhorst (2006), longer bowels may contribute to better nutrient absorption due to it's increased surface.

The gastrointestinal tract is a site of significant growth during the bird's initial phase, then in the first days of post-hatch, the birds go through a period of intense morphological and functional development, implying a limiting factor to the absorption of nutrients (Sell et al., 1991).

For the proventriculus, differences in relative weight were significant $(p<0.05)$ at 7 and 28 days. The birds which received pre-starter feed showed better

Table 4 - Relative digestive system organ's weight ( in body weight) of broiler breeders, in the starter phase, under different feeding programs.

\begin{tabular}{|c|c|c|c|c|}
\hline \multicolumn{5}{|c|}{ Small bowel (\%) } \\
\hline Age & Starter & Starter+probiotics & Pre-starter & Pre-starter + probiotics \\
\hline Day 1 & 5.33 & 4.92 & 5.33 & 4.92 \\
\hline Day 7 & 21.40 & 20.92 & 21.06 & 19.65 \\
\hline Day 14 & 10.74 & 12.66 & 10.49 & 9.94 \\
\hline Day 21 & 9.67 & 10.20 & 11.11 & 10.36 \\
\hline Day 28 & $6.10 \mathrm{~b}$ & $6.40 \mathrm{~b}$ & $9.20 \mathrm{a}$ & $9.10 \mathrm{a}$ \\
\hline \multicolumn{5}{|c|}{ Small bowel length $(\mathrm{cm})$} \\
\hline Age & Starter & Starter+probiotics & Pre-starter & Pre-starter + probiotics \\
\hline Day 1 & 42.6 & 41.8 & 42.6 & 41.8 \\
\hline Day 7 & 85.6 & 80.3 & 83.2 & 80.3 \\
\hline Day 14 & 106.1 & 103.1 & 107.8 & 107.1 \\
\hline Day 21 & 122.5 & 123.9 & 124.5 & 131.3 \\
\hline Day 28 & $128.2 \mathrm{~b}$ & $130.9 \mathrm{~b}$ & $138.2 \mathrm{a}$ & $133.0 \mathrm{ab}$ \\
\hline \multicolumn{5}{|c|}{ Proventriculus (\%) } \\
\hline Age & Starter & Starter+probiotics & Pre-starter & Pre-starter + probiotics \\
\hline Day 1 & 1.11 & 1.03 & 1.11 & 1.03 \\
\hline Day 7 & $1.13 b$ & $1.04 b$ & $1.27 \mathrm{a}$ & $1.33 \mathrm{a}$ \\
\hline Day 14 & 0.78 & 0.80 & 0.86 & 0.82 \\
\hline Day 21 & 0.64 & 0.67 & 0.64 & 0.69 \\
\hline Day 28 & $0.36 b$ & $0.38 b$ & $0.64 a$ & $0.63 a$ \\
\hline \multicolumn{5}{|c|}{ Gizzard (\%) } \\
\hline Age & Starter & Starter+probiotics & Pre-starter & Pre-starter + probiotics \\
\hline Day 1 & 7.28 & 7.47 & 7.28 & 7.47 \\
\hline Day 7 & 8.05 & 7.42 & 7.54 & 8.39 \\
\hline Day 14 & 6.39 & 5.87 & 5.83 & 6.18 \\
\hline Day 21 & 5.31 & 5.20 & 5.00 & 5.06 \\
\hline Day 28 & $2.90 \mathrm{~b}$ & $3.54 \mathrm{~b}$ & $4.32 \mathrm{a}$ & $4.75 \mathrm{a}$ \\
\hline \multicolumn{5}{|c|}{ Cloacal bursa (\%) } \\
\hline Age & Starter & Starter+probiotics & Pre-starter & Pre-starter + probiotics \\
\hline Day 7 & 0.21 & 0.21 & 0.22 & 0.19 \\
\hline Day 14 & 0.25 & 0.28 & 0.28 & 0.27 \\
\hline Day 21 & $0.28 b$ & $0.24 b$ & $0.34 a$ & $0.32 \mathrm{a}$ \\
\hline Day 28 & $0.17 b$ & $0.20 \mathrm{~b}$ & $0.32 \mathrm{a}$ & $0.28 \mathrm{a}$ \\
\hline
\end{tabular}

Values followed by different letters on the same line indicate differences in $T$ test $(p \leq 0.05)$. 
development of the proventriculus when compared to the groups on starter feed alone; this might lead to higher enteric secretion of $\mathrm{HCl}$ and pepsinogen, that ease in breaking protein, improving feed digestion.

Higher gizzard relative weight was observed at 28 days for birds fed with pre-starter feed, that has a higher level of protein than the starter feed, regardless of probiotics, when compared to other treatments. Better gizzard muscle development may contribute to mucosal protection against damages caused by feed and grain pressure; stronger gizzard muscles may also grind feed better, exposing nutrients for absorption (Lilja et al., 1985).

The importance of protein intake on growth and body weight of the birds in the initial stages of development, will approve the diets with higher levels of protein and energy has been recommended by the strains (Sbanotto, 1999). In the present study, the pre-starter diets showed $3.50 \%$ more protein than the starter diets, and may have contributed to further development of the digestive organs.

Higher relative weight of the cloacal bursa was observed at 21 e and 28 days in birds fed with prestarter feed when compared to those fed with starter feed, regardless of probiotics.

The small bowel weight: length ratio allows for an indirect assessment of bowel mucosa growth. Different mucosa densities may represent an increase or decrease in height and diameter of villus, influencing digestive and absorptive capabilities of the gastrointestinal tract (Uni et al., 1998).

Bertechini \& Hossain (1993), Suida (1999) and Zuanon (1995), did not observe an additive effect of probiotics in the start phase, corroborating with our results. This finding may be explained by the fact that no environmental contamination was observed in the first few days of age, and that cleaning and disinfection of floor pens was adequate.

\section{CONCLUSION}

It is possible to conclude that broiler breeder chicks on pre-starter feed during the first seven days of age, are likely to show better physical and productive performances in the adult phase.

\section{REFERENCES}

Bertechini AG, Hossan SM. Utilização de um tipo de probiótico como promotor de crescimento em rações de frangos de corte. Anais da Conferência Apinco de Ciência e Tecnologia Avícola; 1993; Santos, São Paulo. Brasil; 1993. p.1.
Brake JT. Nutrición de broilers, reproductores pesados y abuelos. Anais do 16th Congreso Latino Americano de Avicultura; 1999. Lima, Peru. p. 80-89.

Burnham MR, Peebles ED, Gardner CW, Brake J, Bruzual JJ, Gerard PD. Effects of incubator humidity and hen age on yolk composition in broiler hatching eggs from young breeders. Poultry Science 2001;80:14441450 .

Cobb500. Broiler Performance and Nutrition; 2012. Suplement.

Croom WJ, Brake J, Coles BA. Is intestinal absorption capacity ratelimiting for performance in poultry. Journal of applied Poultry Research $1999 ; 8(2): 242-252$

Dibner J, Richards J, Knight C. Microbial imprinting in gut development and health. Journal Applied Microbiology 2008;17:174.

Godoy JC. Importância da agricultura no Brasil. Rio de Janeiro: União Brasileira de Avicultura;1994.

Jensen LS. Avicultura profissional. Athens 1986;4(2):51-54

Lilburn MS. Pratical aspects of early nutrition for poultry. Journal Applied Poultry Research 1998;7:420-424.

Lilja C, Sperber I, Marks HL. Postnatal growth and organ development in Japanese quail selected for hight growth rate. Growth Hulls Cove 1985;49:51-62.

Penz JR. AM, Vieira S.L. Nutrição na primeira semana. Anais da Conferência Apinco de Ciência e Tecnologia Avícola; 1998; Campinas, São Paulo. Brasil; 1998. p.121-39.

SAS Institute. Statistical analysis system. Release 9.1. (Software). Cary; 2002.

Sbanotto P. Parent stock (Rearing). Total chicken management. Arkansas: World Technical School ; 1999.

Sell JL, Angel CR, Piquer FJ, Mallarino YHA. Development patterns of selected characteristics of the gastrointestinal tract of Young turkeys. Poultry Science 1991;70:1200-1205.

Suida EN. Probióticos em ração para frangos de corte [dissertação]. Lavras (MG): Universidade Federal de Lavras; 1999.

Stringhini JH. Avaliação do desempenho e rendimento de carcaça de quatro linhagens de frangos de corte criadas em Goiás. Revista Brasileira de Zootecnia 2003;32(1):183-190.

Uni Z, Geyra A, Ben-hur H. Small Intestinal development in the young chick: crypt formation and enterocyte proliferation and migration. British Poultry Science 2000;41:544-551.

Uni Z, Ganot S, Sklan D. Post-hatch development of mucosal function in the broiler small intestine. Poultry Science 1998;77:75-82.

Windhorst HW. Changes in poultry production and trade worldwide. World's Poultry Science Journal 2006;62:585-602.

Zuanon JAS, Fonseca JB, Rostagno HS. Efeito de promotores de crescimento sobre o desempenho de frangos de corte. Revista da Sociedade Brasileira de Zootecnia 1998;27(5):999-1005 
